\title{
Traits and Resource Use of Co-Occurring Introduced and Native Trees in a Tropical Novel Forest
}

\author{
Jéssica Fonseca da Silva ${ }^{1,2,3, *}$ [D, Ernesto Medina ${ }^{1,3,4}$ (D) and Ariel E. Lugo ${ }^{1}$ \\ 1 International Institute of Tropical Forestry, USDA Forest Service, Río Piedras 00926-1115, Puerto Rico; \\ medinage@gmail.com (E.M.); alugo@fs.fed.us (A.E.L.) \\ 2 Center for Applied Tropical Ecology and Conservation, University of Puerto Rico, \\ San Juan 00931, Puerto Rico \\ 3 Department of Biology, University of Puerto Rico-Río Piedras, San Juan 00936-8377, Puerto Rico \\ 4 Centro de Ecología, Instituto Venezolano de Investigaciones Científicas, Caracas 1020-A, Venezuela \\ * Correspondence: jefonsecasilva@gmail.com
}

Received: 1 July 2017; Accepted: 6 September 2017; Published: 12 September 2017

\begin{abstract}
Novel forests are naturally regenerating forests that have established on degraded lands and have a species composition strongly influenced by introduced species. We studied ecophysiological traits of an introduced species (Castilla elastica Sessé) and several native species growing side by side in novel forests dominated by C. elastica in Puerto Rico. We hypothesized that C. elastica has higher photosynthetic capacity and makes more efficient use of resources than co-occurring native species. Using light response curves, we found that the photosynthetic capacity of C. elastica is similar to that of native species, and that different parameters of the curves reflected mostly sun light variation across the forest strata. However, photosynthetic nitrogen use-efficiency as well as leaf area/mass ratios were higher for C. elastica, and both the amount of $C$ and $N$ per unit area were lower, highlighting the different ecological strategies of the introduced and native plants. Presumably, those traits support $C$. elastica's dominance over native plants in the study area. We provide empirical data on the ecophysiology of co-occurring plants in a novel forest, and show evidence that different resource-investment strategies co-occur in this type of ecosystem.
\end{abstract}

Keywords: introduced species; leaf $\mathrm{C}$ and $\mathrm{N}$ densities; novel forests; photosynthetic nitrogen use-efficiency; leaf mass per area

\section{Introduction}

The Anthropocene Epoch is associated with rapidly changing environmental conditions and high rates of species introductions, leading to the formation of novel forests [1]. These emerging forests contain species assemblages that include co-occurring introduced and native tree species [2,3]. Novel forests comprise about $35 \%$ of global terrestrial ecosystems [4] and are expected to become more common in the future. There has been much debate in recent years about the implications of novel forests for biodiversity. However, little empirical data are yet available to understand how the tree biota might respond to changing environmental conditions and how this might affect the functioning of present and future forests [5,6].

It is well known that introduced species-commonly the dominant tree species in novel forests-are generally considered a risk for biodiversity due to their ability to outperform native species in terms of productivity, reproductive capacity, and recruitment (e.g., [7,8]). In general, studies report faster growth, higher maximum assimilation rate at saturating light intensities, higher dark respiration and transpiration, more efficient use of resources, and faster nutrient cycling for introduced species compared to native species [9-17]. Usually, introduced species act as pioneers [18] during succession, giving them an advantage in the colonization of disturbed and degraded sites. The ecophysiology of 
native species can be influenced by the effects that introduced species have on novel ecosystems [19], which may be large when introduced species are abundant and dominate the plant community $[19,20]$.

Less is known about species traits and mechanisms that allow native plants to survive and thrive when a novel forest is formed. In a community containing co-occurring native and introduced species, those able to compete efficiently for the same resources, and/or use them in different ways are more likely to persist $[10,15]$. Presumably, native and introduced species occupy different positions in the leaf economic spectrum [10,21-24], which describes the nutrient and organic matter investment of plants on leaf structure and functioning. However, we are unaware of empirical studies demonstrating this pattern in tropical mature novel forests.

We chose a novel forest in Puerto Rico dominated by the introduced tree Castilla elastica Sessé, to study the ecophysiology of co-occurring native and introduced trees. Based on previous studies in the area $[20,25]$ and on the literature, we anticipate that $C$. elastica has a strong influence on the abiotic conditions in this community, which might have effects on the ecophysiology of native species. We hypothesize that $C$. elastica has higher photosynthetic capacity than native species, probably related to its highly efficient use of resources; and that $C$. elastica and native species occupy different regions of the leaf economic spectrum, particularly regarding to leaf area/mass ratios and concentrations of $C$ and $\mathrm{N}$ per unit leaf area. To test our hypotheses, we use photosynthesis light-response curves, and resource use and resource investment indexes to compare species in the community. We also measure the light availability across the forest.

\section{Materials and Methods}

\subsection{Castilla elastica-A Dominant Introduced Tree}

Castilla elastica is one example of a dominant introduced naturalized tree in Puerto Rico, originally from Central and South America [26,27]. The introduction of C. elastica to Puerto Rico happened at the beginning of 20th century according to the local Agricultural Experiment Station in Mayagüez, Puerto Rico. Originally, the government attempted unsuccessfully to produce latex from C. elastica, but also used it as shade tree in coffee plantations. Today, novel forests of $C$. elastica are present throughout Puerto Rico, concentrating in the humid northwest region. These forests covered about 100 hectares in the 1990s, corresponding to less than one percent of the country's land area [26].

\subsection{Study Area}

We studied plants at the biological reserve El Tallonal located in the municipality of Arecibo $\left(18^{\circ} 24^{\prime} 27^{\prime \prime} \mathrm{N} 66^{\circ} 43^{\prime} 53^{\prime \prime} \mathrm{W}\right)$, which is classified as a subtropical moist forest [28]. The predominant soil type at the sinkholes of El Tallonal, where C. elastica is dominant, is the Oxisol of the series Almirante [29]. The annual mean temperature and precipitation are $25.5^{\circ} \mathrm{C}$ and $1295 \mathrm{~mm}$, respectively. The dry season is from January to April, and the wettest months are July to September.

Agriculture and cattle grazing were common activities at El Tallonal until the 1950s, and it is likely that C. elastica was introduced in the area around 1940s and then abandoned few years later. Forest regeneration occurred naturally after land abandonment, and aerial photographs show that areas covered by novel forests of C. elastica had been growing for about 50 years by 2005 . Currently, C. elastica has a mean species Importance Value Index of 37\% (a composite index of relative density, cover, and frequency) in these forests, indicating that the species occupies a dominant position [25]. The forest is referred to hereafter as Castilla novel forest. Modifications on species composition and functioning in the study area have been associated with the dominance of this species [20,25].

\subsection{Sampling}

We measured in situ photosynthetic light responses of leaves of C. elastica and of co-occurring native species (Table 1). To that end, we took advantage of two $26 \mathrm{~m}$-tall meteorological towers standing in the study site that allowed data collection at different heights or forest strata, i.e., canopy $=25 \mathrm{~m}$ in 
height, subcanopy = $15 \mathrm{~m}$ in height and understory = ground level to two meters in height. Large trees $(\geq 10 \mathrm{~cm}$ of diameter at breast height $(\mathrm{DBH}))$, assumed as adult trees, were measured in the canopy and in the subcanopy. Saplings $(1.5 \leq \mathrm{DBH}<2.5 \mathrm{~cm}$, between one and two $\mathrm{m}$ in height), and juvenile plants (seedlings and young individuals of 10 to $40 \mathrm{~cm}$ in height) were measured in the understory. The number of trees and species that could be measured and sampled from the towers was limited, imposing restrictions on the statistical analyses. However, the same trees could be repeatedly measured throughout an entire year, compensating partially for the small number of individuals measured.

Sampling campaigns were performed during periods of contrasting rainfall and temperature. For practical purposes, below we refer to each measuring period as follows: December to January as December 2008; March to April as March 2009; June to July as June 2009; and October to November as November 2009.

In the canopy, we selected two trees of C. elastica and two of native species. In the subcanopy, we measured a C. elastica tree and one tree of native species (the only one present at this forest stratum). In the understory, we measured four saplings: two of C. elastica and two of native species. For juvenile plants, we selected six individuals on each sampling event (three of C. elastica and three of native species), and measured one leaf per individual, instead of two. Each pair of leaves and trees (native and introduced) was measured at the same level to ensure they were exposed to a similar light environment. In total, we obtained at least two light response curves, per species, per measuring period (except in the case of a few juvenile plants that were represented by a single curve), for a total of 92 light response curves. Plants in the subcanopy and understory were only measured during December 2008, March 2009, and June 2009.

Table 1. List of species analyzed, their botanical families, and the forest stratum at novel Castilla forests. Taxonomic classification follows [26,30].

\begin{tabular}{|c|c|c|}
\hline Species & Family & Forest Stratum \\
\hline Casearia guianensis (Aubl.) Urban $\mathrm{N}$ & Flacourtiaceae & Us \\
\hline Casearia sylvestris Sw. $\mathrm{N}$ & Flacourtiaceae & SC \\
\hline Castilla elastica Sessé In & Moraceae & C, SC, Us \\
\hline Chrysophyllum argenteum Jacques $\mathrm{N}$ & Sapotaceae & Us \\
\hline Cordia alliodora (Ruiz \& Pav.) ${ }^{\mathrm{N}}$ & Boraginaceae & $\mathrm{C}$ \\
\hline Faramea occidentalis (L.) A. Rich ${ }^{N}$ & Rubiaceae & Us \\
\hline Guarea guidonia (L.) Sleumer ${ }^{N}$ & Meliaceae & Us \\
\hline Ocotea floribunda (Sw.) $\mathrm{Mez}^{\mathrm{N}}$ & Lauraceae & $\mathrm{C}$ \\
\hline Ocotea leucoxylon (Sw.) $\mathrm{Mez}^{\mathrm{N}}$ & Lauraceae & C \\
\hline Thouinia striata Radlk $\mathrm{Ne}$ & Sapindaceae & Us \\
\hline Trichilia pallida $\mathrm{Sw}_{\mathrm{w}} \mathrm{N}$ & Meliaceae & Us \\
\hline
\end{tabular}

In = introduced naturalized, $\mathrm{N}=$ native, and $\mathrm{Ne}=$ native endemic species; $\mathrm{C}=$ Canopy, $\mathrm{SC}=\mathrm{Sub}$ canopy and Us = Understory.

Environmental data were recorded using a HOBO micro-station data logger (H21-002, Onset Computer Corporation, Bourne, MA, USA). Three micro stations were installed in each tower and forest strata: canopy $\left(26 \mathrm{~m}\right.$ in height), subcanopy $(15 \mathrm{~m})$ and understory $(1.5 \mathrm{~m})$. Air temperature $\left({ }^{\circ} \mathrm{C}\right)$, photosynthetic photon flux density (PPFD, $\mu \mathrm{mol} \mathrm{m}{ }^{-2} \mathrm{~s}^{-1}$ ) and air relative humidity (percent) were recorded from December 2008 to November 2009. Care was taken to ensure that environmental data recorded by loggers were representative of leaf conditions.

\subsection{Light Response Curves and Leaf Harvesting Protocol}

Light response curves were measured in the field, using a portable infrared gas analyser (LCpro+, ADC BioScientific Ltd., Hertfordshire, UK). The LCpro+ analyses the difference between ambient $\mathrm{CO}_{2}$ concentration and the concentration of $\mathrm{CO}_{2}$ in a leaf chamber $(\Delta \mathrm{c})$, and calculates $\mathrm{CO}_{2}$ assimilation rate $\left(\mathrm{A}\right.$, in $\left.\mu \mathrm{mol} \mathrm{m} \mathrm{m}^{-2} \mathrm{~s}^{-1}\right)$ and stomatal conductance to water vapour (gs, in $\mathrm{mol} \mathrm{m}^{-2} \mathrm{~s}^{-1}$ ). 
Gas exchange measurements were performed in the morning, after leaves had received natural illumination for at least two hours. In the canopy and subcanopy, we measured $\mathrm{CO}_{2}$ assimilation in response to increasing light intensity from dark conditions (zero) to $2000 \mu \mathrm{mol} \mathrm{m} \mathrm{m}^{-2} \mathrm{~s}^{-1}$ of photosynthetic photon flux density (PPFD), using the following sequence: 0, 100, 250, 500, 1000, 1500 and $2000 \mu \mathrm{mol} \mathrm{m}{ }^{-2} \mathrm{~s}^{-1}$. In the understory, we used PPFD from zero to $600 \mu \mathrm{mol} \mathrm{m}{ }^{-2} \mathrm{~s}^{-1}$, using the following sequence: $0,50,100,200,400$ and $600 \mu \mathrm{mol} \mathrm{m}^{-2} \mathrm{~s}^{-1}$. We allowed enough time between changes in light intensity to ensure leaf equilibration. Temperature was kept constant at $25^{\circ} \mathrm{C}$ and $\mathrm{CO}_{2}$ concentration was maintained at about 380 volume per million (vpm) to avoid short term variations that would render measurements meaningless. After conducting each light response curve, leaves were harvested to measure the leaf area, leaf mass and leaf carbon and nitrogen concentrations.

Light response curve data were then analysed using a non-linear mixed model as follows: $\mathrm{A}=\mathrm{A}_{\max }{ }^{*}\left(1-\mathrm{e}^{-\alpha(\text { PPFD-LCP) }}\right)$ [31]. Sigma Plot (v.11.0, Systat Software Inc., San Jose, CA, USA) was used to fit the curves and calculate the following parameters: maximum photosynthetic rate at saturating light intensities $\left(\mathrm{A}_{\max }\right)$, light compensation point (LCP), light saturation point (LSP), dark respiration and quatum yield. We also calculated the stomatal conductance of water vapour at maximum $A$ rates $\left(\mathrm{gs}_{\max }\right.$, in $\left.\operatorname{mol~m} \mathrm{m}^{-2} \mathrm{~s}^{-1}\right)$, the intrinsic water use efficiency at maximum rates $\left(\mathrm{WUE}_{\mathrm{i}}\right)$ as the molar ratio of $\mathrm{A}_{\max }$ and $\mathrm{gs}_{\max }\left(\right.$ in $\mu \mathrm{mol} \mathrm{mol}^{-1}$ ), and the photosynthetic nitrogen use efficiency (PNUE) per unit of leaf nitrogen at maximum assimilation rates (PNUE $=\mathrm{A}_{\max } /$ nitrogen content, in $\left.\mu \mathrm{mol} \mathrm{mol}{ }^{-1} \mathrm{~s}^{-1}\right)$.

\subsection{Samples Processing}

Leaf area of fresh leaves was measured using a leaf area meter (LI-3100, LI-COR Biosciences, Lincoln, NE, USA). After that, leaves were dried in the oven at $65^{\circ} \mathrm{C}$ for at least three days, and then weighed to obtain their dry mass. Leaf surface area $\left(\mathrm{m}^{2}\right)$, leaf dry mass $(\mathrm{kg})$, and leaf mass per area (LMA in $\mathrm{kg} \mathrm{m}^{-2}$ ), were determined to compare leaf structure among species and groups [32]. Leaf carbon and nitrogen concentrations were measured by macro dry combustion using a LECO CNS-2000 analyser (LECO Corporation, St. Joseph, MI, USA). Molar N concentrations are given on both area $\left(\mathrm{m}^{2}\right)$ and mass basis $(\mathrm{kg})$.

\subsection{Statistical Analyses}

All analyses were performed using JMP 13.0 (SAS Institute Inc., Cary, NC, USA). Differences in environmental conditions between forest strata were tested using an Analysis of Variance (ANOVA) and posterior Tukey test for differences among measuring periods. Normality tests showed that biological parameters were not normally distributed, therefore we used nonparametric tests analogous to one-way analysis of variance (Wilcoxon/Kruskal-Wallis test, at maximum $p=0.05$ ), or multiple pair-wise contrasts (Wilcoxon z), for comparing the photosynthetic capacity parameters, LMA, and C and $\mathrm{N}$ concentrations.

The set of native species available for measurement around the tower area was treated as a single group as there were no significant statistical differences in their photosynthetic parameters. This group was compared to the set of $C$. elastica measurements at every sampling season and stratum (canopy, subcanopy and understory). Linear regression analysis was used to test the relationship between leaf area and leaf mass, and the concentrations of $\mathrm{C}$ and $\mathrm{N}$.

\section{Results}

\subsection{Environmental Conditions}

Mean precipitation and temperature range for each period were the following: December (149 $\mathrm{mm}$, and 18 to $\left.27^{\circ} \mathrm{C}\right)$, March $\left(33 \mathrm{~mm}\right.$, and 20 to $\left.28^{\circ} \mathrm{C}\right)$, June $\left(144 \mathrm{~mm}\right.$, and 23 to $31^{\circ} \mathrm{C}$ ) and November $\left(189 \mathrm{~mm}\right.$, and 22 to $30^{\circ} \mathrm{C}$ ). Throughout the year, mean temperature varied from 20 to $24{ }^{\circ} \mathrm{C}$ with a peak in June. The relative humidity was over $80 \%$ for almost the entire study period. 
Light intensity ( $\mathrm{PPFD}_{\text {mean }}$ ) varied from the understory to the canopy by two orders of magnitude: from about 6 to more than $700 \mu \mathrm{mol} \mathrm{m}{ }^{-2} \mathrm{~s}^{-1}$ (Figure 1). The average PPFD mean per day in the canopy was $686 \mu \mathrm{mol} \mathrm{m}^{-2} \mathrm{~s}^{-1}$, and the average daily PPFD sum was $30 \mathrm{~mol} \mathrm{~m}^{-2} \mathrm{day}^{-1}$. The PPFD mean received in the subcanopy and in the understory were only $10 \%$ and $1 \%$ of that received in the canopy, respectively. The photoperiod (the total hours in a day during which the PAR sensors record incident and diffuse sunlight in each stratum), varied throughout the year between 12 and $13 \mathrm{~h}$ in the canopy and subcanopy, and between 8 and 11 in the understory. Both the PPFD mean and PPFD sum did not differ between dates in the canopy, but they were significantly higher during March and June season in both the subcanopy and the understory, coinciding with the pronounced leaf shedding of C. elastica trees $[20,25]$.

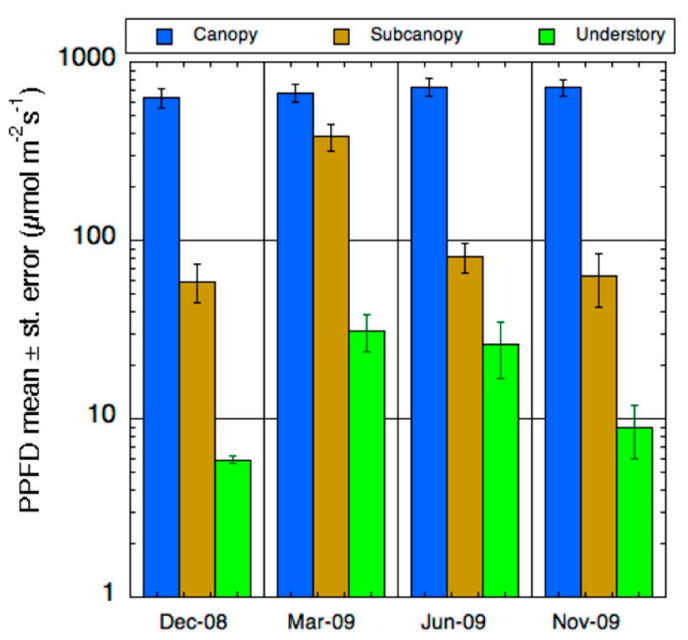

(A)

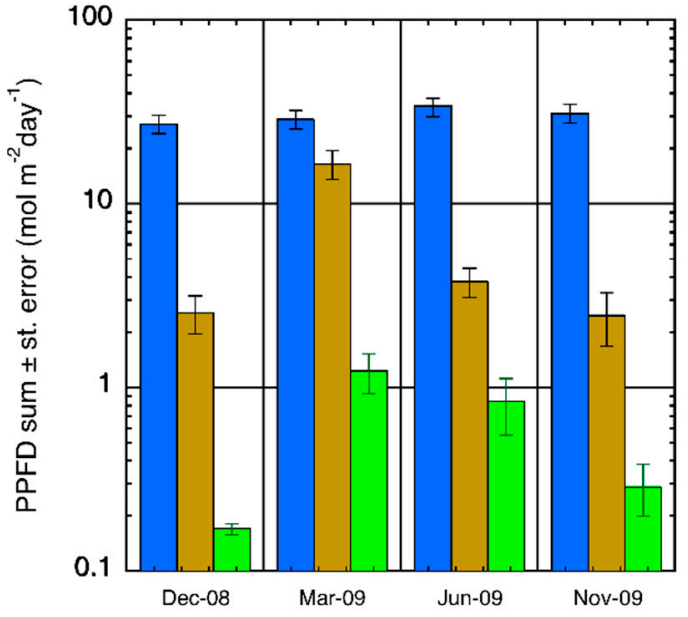

(B)

Figure 1. Environmental variables at Castilla novel forest. (A) Mean photosynthetic photon flux density $\left(\mathrm{PPFD}_{\text {mean }}\right)$ and $(\mathbf{B})$ total photosynthetic photon flux density $\left(\mathrm{PPFD}_{\text {sum }}\right)$ per day for the different forest strata during four measuring periods $(n=60-62)$.

\subsection{Leaf Dimensions}

Castilla elastica produced larger and heavier leaves compared to the group of native species (Figure 2). In addition, their LMA was lower and decreased 3.3 times from the canopy to the understory. For the group of native species, the same pattern was observed but the decrease in LMA was less pronounced (2.2 times), indicating lower plasticity of this parameter.

\subsection{Concentration of $C$ and $N$, and $C: N$ Ratios}

Median C concentration of the native species was $43 \mathrm{~mol} \mathrm{~kg}^{-1}$, ranging from 35 to $47 \mathrm{~mol} \mathrm{~kg}^{-1}$, whereas C. elastica had a narrower range (34 to $\left.40 \mathrm{~mol} \mathrm{~kg}^{-1}\right)$ and a lower median $\left(38 \mathrm{~mol} \mathrm{~kg}^{-1}\right)$ (Groups differed significantly: Wilcoxon/Kruskal-Wallis $\chi^{2}=35,0.001<\chi^{2}<p$ ). In the case of leaf $\mathrm{N}$ concentration, grouped native species had a median of 1.7 (range: 1.2 to $2.2 \mathrm{~mol} \mathrm{~kg}^{-1}$ ), whereas C. elastica had a significantly larger median leaf $\mathrm{N}$ concentration $\left(2.05 \mathrm{~mol} \mathrm{~kg}^{-1}\right)$ and a range between 1.3 and $2.4 \mathrm{~mol} \mathrm{~kg}^{-1}$ (Wilcoxon/Kruskal-Wallis $\chi^{2}=16,0.001<\chi^{2}<p$ ). 

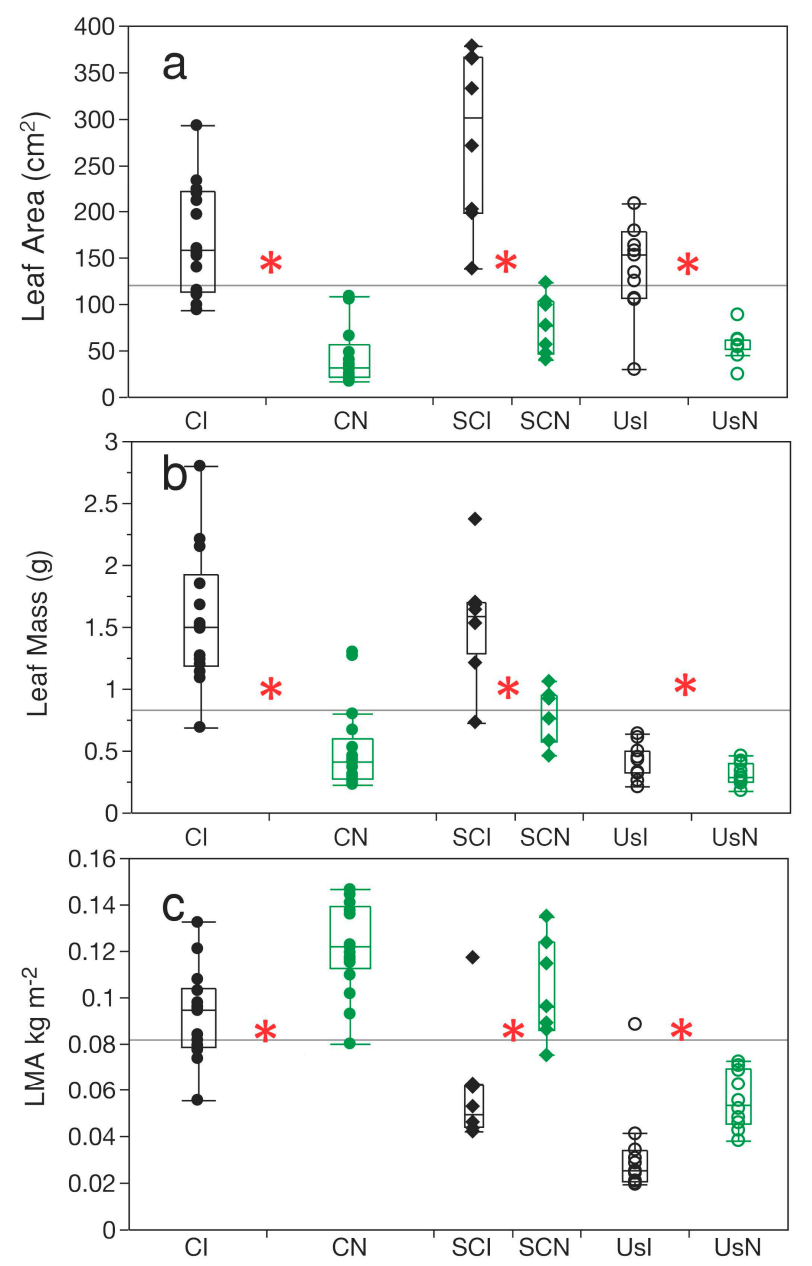

Figure 2. (a) Leaf area; (b) leaf mass and (c) leaf mass per area (LMA) of C. elastica (I) (black symbols) and group of native species (N) (green symbols) measured in the canopy (C), subcanopy (SC), and understory (Us) of a Castilla novel forest. Number of samples: $\mathrm{CI}=14, \mathrm{CN}=16, \mathrm{SCI}=8, \mathrm{SCN}=7$, $\mathrm{UsI}=11, \mathrm{UsN}=10$. The red asterisks indicate significant differences between groups within each stratum (Wilcoxon $\mathrm{z}, p<0.01$ ).

The LMA values of both groups increased from the understory to the canopy, and as expected, $\mathrm{C}$ concentration per unit area was linearly correlated with the LMA in both groups, with a slightly higher slope for grouped native species (Figure 3). The same pattern was observed in the case of $\mathrm{N}$ concentration per area $\left(\mathrm{N}_{\text {area }}\right)$, although the models explained lower percentages of data variance in comparison to those for $\mathrm{C}$ concentrations. The continuous and rapid increase of $\mathrm{C}$ and $\mathrm{N}$ per unit area from the understory to the canopy in both groups is expected as a response to the higher light energy available for photosynthesis in the upper forest strata.

Within each stratum, median C:N ratios were significantly lower for C. elastica (Figure 4). For this species, the ratio decreased markedly from the canopy to the understory, whereas no uniform pattern was observed for the grouped native species. 


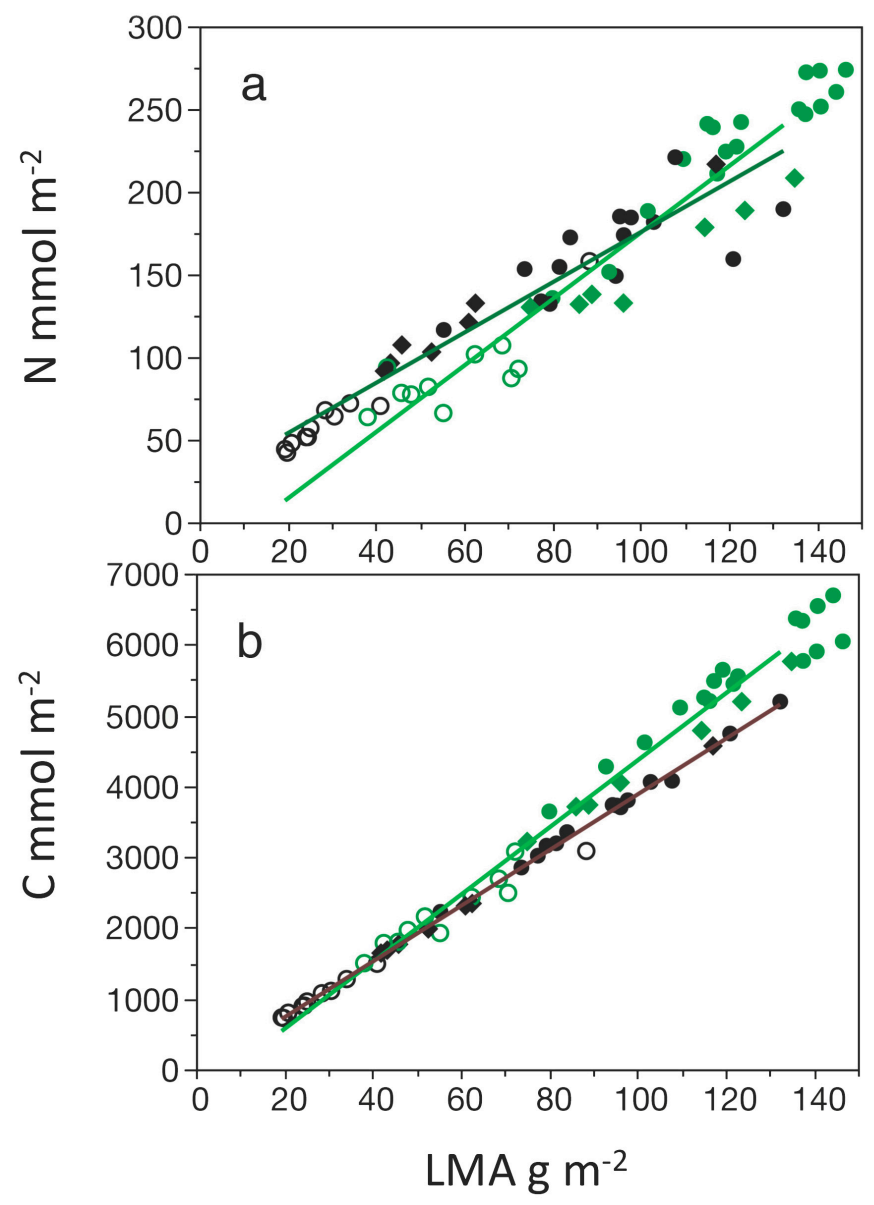

Figure 3. Variations of the relationship between leaf mass per area (LMA) and (a) N and (b) C concentrations per unit area in the vertical profile of the Castilla novel forest. Green symbols: native species; black symbols: C. elastica. Open circles (Us), squares (SC), closed circles (C). For, native species: $\mathrm{C}=-380+47,000$ LMA, $R^{2}=0.97 ;$ and $\mathrm{N}=-26+2000 \mathrm{LMA}, R^{2}=0.92(n=34)$. For C. elastica: $\mathrm{C}=-53+39,000$ LMA, $R^{2}=0.99 ;$ and $\mathrm{N}=23.4+1500 \mathrm{LMA}, R^{2}=0.91(n=33)$.

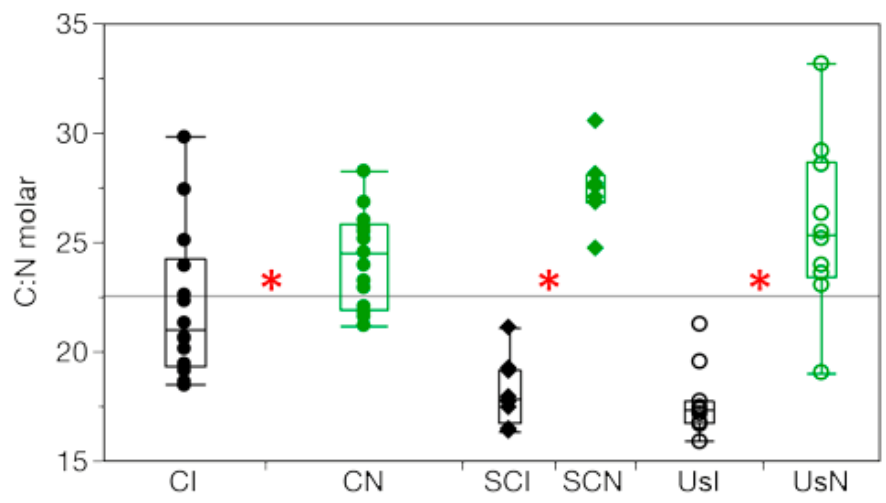

Figure 4. Vertical variation in leaf $\mathrm{C}: \mathrm{N}$ ratios for C. elastica (I) (black symbols) and grouped native species (N) (green symbols) measured in the canopy (C), sub-canopy (SC), and understory (Us) of a Castilla novel forest. The stars indicate significant differences between groups within each stratum (Wilcoxon test, $p<0.05$ ). Overall comparison between C. elastica and the group of native species: Wilcoxon/Kruskal-Wallis test $\chi^{2}=44,0.001<\chi^{2}<p$. 


\subsection{Comparisons Among Photosynthetic Capacity and Other Physiological Traits}

We found no differences among species and across measuring periods when comparing photosynthetic parameters from the controlled light response curves. However, these parameters varied between forest strata and were always higher in the canopy than in the subcanopy and understory, respectively (Table 2). The lack of differences among groups within each forest stratum indicates similar adaptability of the photosynthetic apparatus in both introduced and native species. In addition, both gs $s_{\max }\left(0.24\right.$ to $0.40 \mathrm{~mol} \mathrm{~m}^{-2} \mathrm{~s}^{-1}$ for all species) and $W_{U E_{i}}$ ( 89 to 51 and 11 to $63 \mu \mathrm{mol}$ $\mathrm{mol}^{-1}$, for C. elastica and grouped native species respectively) overlapped in both the introduced and native species groups, across all strata and measuring periods.

Photosynthetic rate per area was linearly and positively related to the $\mathrm{N}$ concentration per unit area in both groups (Figure 5a), with a slightly greater gradient for C. elastica. Unexpectedly, the regression between $\mathrm{A}_{\max }$ and $\mathrm{N}$ concentration per unit mass was significant only for C. elastica (Figure 5b).

Table 2. Median \pm Median Absolute Deviation (number of observations) for the main photosynthetic parameters in the Castilla forest at El Tallonal. Medians differed between group of species per stratum, except for $A_{\max }$ per unit mass.

\begin{tabular}{|c|c|c|c|c|}
\hline \multirow[b]{2}{*}{ Stratum } & \multicolumn{2}{|c|}{ Amax } & LCP & LSP \\
\hline & $\mu \mathrm{mol} \mathrm{kg} \mathrm{kg}^{-1} \mathrm{~s}^{-1}$ & $\mu \mathrm{mol} \mathrm{m} \mathrm{m}^{-2} \mathrm{~s}^{-1}$ & \multicolumn{2}{|c|}{$\mu \mathrm{mol} \mathrm{m}{ }^{-2} \mathrm{~s}^{-1}$} \\
\hline Canopy & $104.4 \pm 18.8(31)$ & $11.3 \pm 1.6(34)$ & $22.6 \pm 3.2$ & $927 \pm 57$ \\
\hline Subcanopy & $113.8 \pm 25.4(15)$ & $7.6 \pm 1.7(19)$ & $15.2 \pm 3.5$ & $775 \pm 122$ \\
\hline Understory & $127.1 \pm 42.6(21)$ & $4.9 \pm 1.0(26)$ & $9.6 \pm 1.9$ & $275 \pm 57$ \\
\hline$\chi^{2}$ Wilcoxon/Kruskal-Wallis & $p=0.462$ & $p<0.0001$ & $p<0.0001$ & $p<0.0001$ \\
\hline
\end{tabular}
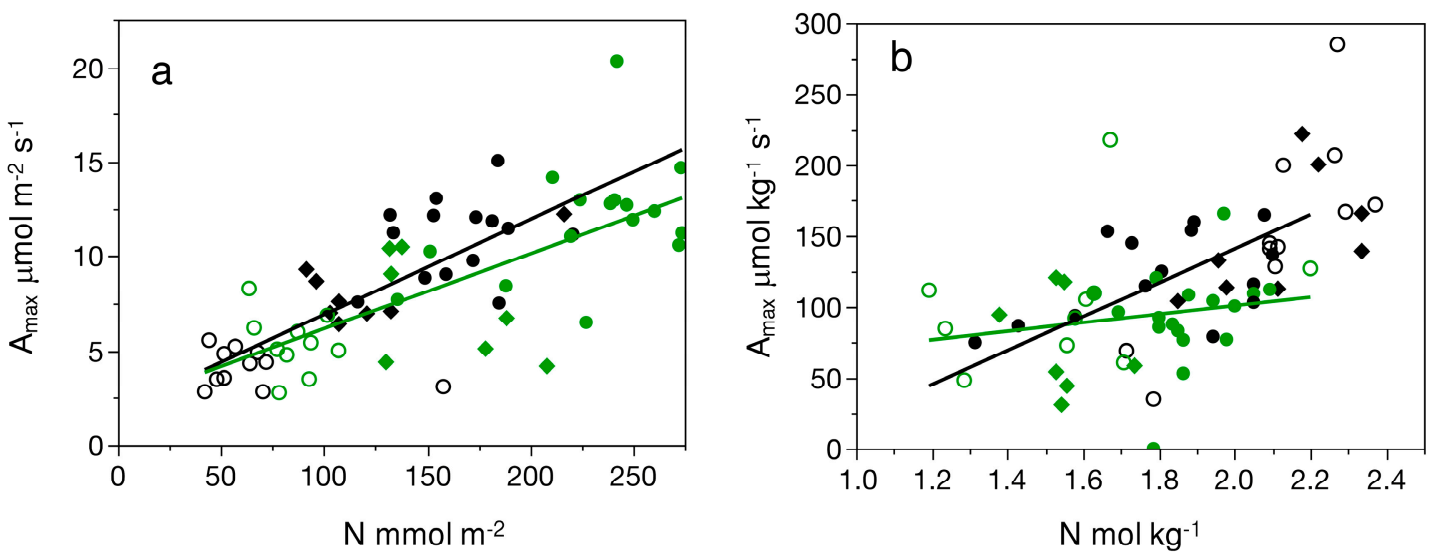

Figure 5. Relationship between $A_{\max }$ and $N$ concentration per unit area $\left(A_{\max }\right.$ area, $\left.(\mathbf{a})\right)$, and unit mass $\left(\mathrm{A}_{\text {max mass }},(\mathrm{b})\right)$. Symbols as in Figure 3. For C. elastica, $\mathrm{A}_{\max \text { area }}=1.87+0.05 \mathrm{~N}_{\text {area }}, R^{2}$ adj $=0.59, \mathrm{~F}=47$, $p>\mathrm{F}<0.0001, n=33 ; \mathrm{A}_{\text {max mass }}=-97.9+119.4 \mathrm{~N}_{\text {mass }}, R^{2}{ }_{\text {adj }}=0.38, \mathrm{~F}=21, p>\mathrm{F}<0.0001$. For the group of native species, $\mathrm{A}_{\text {max area }}=2.18+0.04 \mathrm{~N}_{\text {area }}, R^{2}$ adj $=0.50, \mathrm{~F}=31, p>\mathrm{F}<0.0001, n=33 ; R^{2}$ adj $=0.005$, not significant.

\subsection{Photosynthetic Nitrogen Use-Efficiency}

Within each stratum, C. elastica had median values above the overall mean, but significant differences between C. elastica and the native species group were found only at the canopy level (Figure 6a). Castilla elastica showed a higher PNUE compared to all native species when data was pooled together (median of 67.5 and $53.7 \mu \mathrm{mol} \mathrm{CO} \mathrm{mol}^{-1} \mathrm{~N} \mathrm{~s}^{-1}$, for C. elastica and grouped native species, respectively) (Figure 6b). 

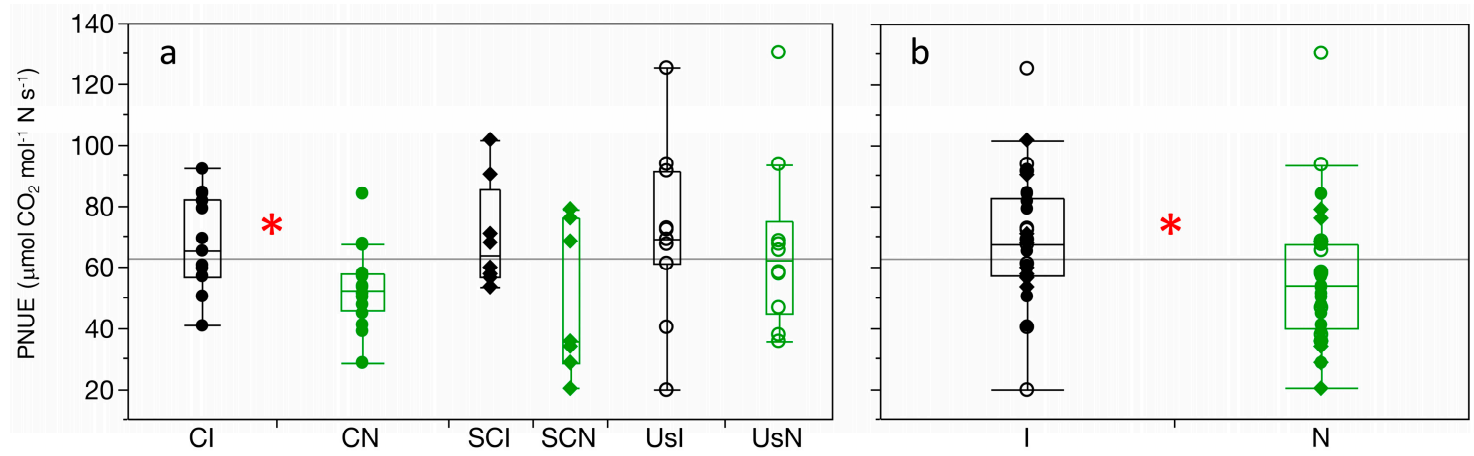

Figure 6. Comparison of photosynthetic nitrogen use-efficiencies for Castilla elastica = (I) (black symbols) and group of native species $(\mathrm{N})$ (green symbols). The red asterisk indicates significant differences between groups of species (Wilcoxon and Wilcoxon/Kruskal-Wallis tests). (a) Photosynthetic nitrogen use efficiency per stratum and groups of species $(\mathrm{CI}>\mathrm{CN}$, Wilcoxon $\mathrm{z}$ value $=2.66, p=0.0078)$ and (b) comparison between I and $\mathrm{N}$ (Wilcoxon/Kruskal-Wallis $\chi^{2}=8.8, p>\chi^{2}=0.0031$ ).

\section{Discussion}

\subsection{Castilla elastica Influences the Irradiance Below the Canopy}

The novel forest under study has been regenerating for at least 60 years and already presents a complex canopy structure [25]. This complex canopy drives the vertical differences in PPFD across strata. The understory only receives a tiny proportion of the total irradiance that reaches the canopy $(\sim 1 \%)$. Clark et al. [33], in a study of mature tropical forests, also reported that only $1 \%$ to $2 \%$ of the photosynthetically active radiation reaches the understory.

Below the canopy, the PPFD varied across seasons, probably because of changes in leaf area index. The fact that C. elastica is a deciduous tree, and loses its leaves during the dry season $[20,26,34]$, promotes high variation in the irradiance received in the subcanopy (8-50\%) and in the understory throughout the year $(<1 \%$ to $4 \%)$. These changes probably influence the ecophysiology of the whole plant community in the area.

\subsection{Similar Photosynthetic Capacity and Water Use Among Species}

Species groups varied little in their photosynthetic capacities and water use $\left(\mathrm{A}_{\max }, \mathrm{gs}_{\max }\right.$, and $W E_{i}$ ) when comparing plants within the same forest stratum. This resulted in similar carbon gain among species. This similarity in photosynthetic capacities was unexpected, because introduced species often have higher photosynthetic capacity and resource gain than native species $[9,15,35]$. Instead, the differences that were found across forest strata demonstrated leaf adjustment to the large differences in irradiance and reflected the different stages of plant development.

Photosynthetic characteristics of upper canopy leaves of C. elastica in moist forests in Panama were studied in detail by Kitajima et al. [36]. Leaves developed in the early wet season were compared to those developed in the pre-dry season. The study showed that C. elastica did not exhibit seasonal phenotypes. There were no significant differences from early wet season to pre-dry season for the following indicators: light saturated oxygen evolution, nitrogen content per unit mass, photosynthetic $\mathrm{N}$ use efficiency, and LMA. Maximum $\mathrm{CO}_{2}$ assimilation rates and nitrogen concentrations of $C$. elastica canopy leaves in Panama overlap the values reported here. However, LMA values are much lower in Panama (0.065-0.077 $\left.\mathrm{kg} \mathrm{m}^{-2}\right)$ than in our study $\left(0.093 \mathrm{~kg} \mathrm{~m}^{-2}\right)$, which can probably be explained by the different methods used for measuring the leaves.

\subsection{Nitrogen Use-Efficiency and Leaf Area Are Advantages for Castilla elastica}

Castilla elastica adult trees showed the most efficient use of nitrogen in photosynthesis, particularly at the canopy and subcanopy strata, where light energy was not limiting photosynthesis. Thus, 
similarly to introduced species in general, C. elastica outperformed native species in this aspect. This feature could contribute to explain C. elastica's dominance in this novel forest. It is remarkable that we found significant linear relationships between $\mathrm{N}$ and photosynthesis per unit area but not per unit mass, as is usually reported in other sites [37]. Values of PNUE for the native species group reported here are comparable to those of late successional species elsewhere (29-84 vs. $56 \mu \mathrm{mol} \mathrm{CO} 2 \mathrm{~mol}^{-1} \mathrm{~N} \mathrm{~s}^{-1}$ ) [37], while those of C. elastica are much lower than those of early successional species (41-92 vs. $216 \mu \mathrm{mol} \mathrm{CO} \mathrm{mol}^{-1} \mathrm{~N} \mathrm{~s}^{-1}$ ).

Leaf mass per area of $C$. elastica was significantly lower than that of native species. This shows that $C$. elastica's leaves are less expensive because they attain similar photosynthetic rates as that of native species while investing a lot less $C$ and N. Moreover, $C$. elastica showed higher plasticity than native species, by adjusting to the different irradiance across forest strata, as suggested by the different leaf mass/area relationships across strata. Phenotypic plasticity is usually high in introduced species for a number of traits, including LMA [38]. Although high plasticity does not always indicate better performance, this is usually the case and can give an advantage to introduced species in their new habitat $[14,39]$. In the case of $C$. elastica, plasticity in LMA seems to have contributed to its dominance in the new range.

Leaf mass per area of C. elastica adult plants was in the range of variation for those reported by Reich et al. [39] for deciduous and pioneer woody plants in tropical forests $\left(0.03-0.4 \mathrm{~kg} \mathrm{~m}^{-2}\right)$. We found even lower LMA for saplings and juvenile plants of C. elastica $\left(0.015-0.02 \mathrm{~kg} \mathrm{~m}^{-2}\right)$. Low LMA is often associated with a high relative growth rate and invasiveness [40-47]. Investing resources in less expensive leaves (i.e., low LMA) might result in more efficient light interception for C. elastica in comparison to native species.

\section{Conclusions}

Overall, photosynthetic capacity was unexpectedly similar among species in the Castilla novel forest. High PNUE and low LMA support $C$. elastica's higher competitive capacity over native species and could explain its dominance in this novel ecosystem. These results contradict our hypothesis of higher photosynthetic capacity for C. elastica, but support the hypothesis of more efficient use of resources ( $\mathrm{C}$ and $\mathrm{N}$ ) by the introduced species. The results also indicate that introduced and native species do not occupy overlapping positions in the leaf economic spectrum.

Acknowledgments: This research project was supported by the International Institute of Tropical Forestry (Institute), USDA-Forest Service, the Center for Applied Tropical Ecology and Conservation, the University of Puerto Rico, and Ciudadanos del Karso. The work was done in collaboration with the University of Puerto Rico. We are grateful to Abel Vale, the owner of El Tallonal, who allowed us to conduct the study in his property. We thank Humberto Robles, Oscar Abelleira, Jasmine Shaw, Seth Rifkin, Dylan Rhea and Omar Gutiérrez for helping in the sampling and field data collection. We are grateful to Humberto Robles, Maricel Beltrán, Ariana Beltrán and Edgardo Valcárcel who helped to process the leaf samples. Thanks to the staff of the Institute's Chemistry Lab for conducting the chemical analyses of leaf material. We are also grateful to Pascal Bugnion for English language editing on this manuscript.

Author Contributions: J.F.d.S., E.M. and A.E.L. conceived the ideas and designed the methodology; J.F.d.S. collected the data; J.F.d.S. and E.M. analyzed the data and led the writing of the manuscript. All authors contributed critically to the drafts and gave final approval for publication.

Conflicts of Interest: The authors declare no conflict of interest.

\section{References}

1. Malhi, Y.; Gardner, T.A.; Goldsmith, G.R.; Silman, M.R.; Zelazowski, P. Tropical forests in the Anthropocene. Annu. Rev. Environ. Resour. 2014, 39, 125-159. [CrossRef]

2. Lugo, A.E.; Helmer, E. Emerging forests on abandoned land: Puerto Rico's new forests. For. Ecol. Manag. 2004, 190, 145-161. [CrossRef] 
3. Hobbs, R.J.; Arico, S.; Aronson, J.; Baron, J.S.; Bridgewater, P.; Cramer, V.A.; Epstein, P.R.; Ewel, J.J.; Klink, C.A.; Lugo, A.E.; et al. Novel ecosystems: Theoretical and management aspects of the new ecological world order. Glob. Ecol. Biogeogr. 2006, 15, 1-7. [CrossRef]

4. Hobbs, R.J.; Higgs, E.S.; Hall, C. Novel Ecosystems: Intervening in the New Ecological World Order, 1st ed.; John Wiley \& Sons Ltd.: Chichester, UK, 2013.

5. Higgs, E. Novel and designed ecosystems. Restor. Ecol. 2017, 25, 8-13. [CrossRef]

6. Corlett, R.T. The Anthropocene concept in ecology and conservation. Trends Ecol. Evol. 2015, 30, 36-41. [CrossRef] [PubMed]

7. Alpert, P. The advantages and disadvantages of being introduced. Biol. Invasions 2006, 8, 1523-1534. [CrossRef]

8. Pyšek, P.; Jarošík, V.; Hulme, P.E.; Pergl, J.; Hejda, M.; Schaffner, U.; Vilà, M. A global assessment of invasive plant impacts on resident species, communities and ecosystems: The interaction of impact measures, invading species' traits and environment. Glob. Chang. Biol. 2012, 18, 1725-1737. [CrossRef]

9. Pattison, R.R.; Goldstein, G.; Ares, A. Growth, biomass allocation and photosynthesis of invasive and native Hawaiian rainforest species. Oecologia 1998, 117, 449-459. [CrossRef] [PubMed]

10. Baruch, Z.; Goldstein, G. Leaf construction cost, nutrient concentration, and net $\mathrm{CO}_{2}$ assimilation of native and invasive species in Hawaii. Oecologia 1999, 121, 183-192. [CrossRef] [PubMed]

11. McDowell, S.C.L. Photosynthetic characteristics of invasive and noninvasive species of Rubus (Rosaceae). Am. J. Bot. 2002, 89, 1431-1438. [CrossRef] [PubMed]

12. Burns, J.H. A comparison of invasive and noninvasive dayflowers (Commelinaceae) across experimental nutrient and water gradients. Divers. Distrib. 2004, 10, 387-397. [CrossRef]

13. Leicht Young, S.A.; Silander, J.A., Jr.; Latimer, A.M. Comparative performance of invasive and native Celastrus species across environmental gradients. Oecologia 2007, 154, 273-282. [CrossRef] [PubMed]

14. Funk, J.L. Differences in plasticity between invasive and native plants from a low resource environment. J. Ecol. 2008, 96, 1162-1173. [CrossRef]

15. Peñuelas, J.; Sardans, J.; Llusià, J.; Owen, S.M.; Carnicer, J.; Giambelluca, T.W.; Rezende, E.L.; Waite, M.; Niinemets, Ü. Faster returns on "leaf economics" and different biogeochemical niche in invasive compared with native plant species. Glob. Chang. Biol. 2010, 16, 2171-2185. [CrossRef]

16. Cavaleri, M.A.; Sack, L. Comparative water use of native and invasive plants at multiple scales: A global meta-analysis. Ecology 2010, 91, 2705-2715. [CrossRef] [PubMed]

17. Lamarque, L.J.; Delzon, S.; Lortie, C.J. Tree invasions: A comparative test of the dominant hypotheses and functional traits. Biol. Invasions 2011, 13, 1969-1989. [CrossRef]

18. Whitmore, T.C. Canopy gaps and the two major groups of forest trees. Ecology 1989, 70, 536-538. [CrossRef]

19. Didham, R.K.; Tylianakis, J.M.; Gemmell, N.J.; Rand, T.A.; Ewers, R.M. Interactive effects of habitat modification and species invasion on native species decline. Trends Ecol. Evol. 2007, 22, 489-496. [CrossRef] [PubMed]

20. Fonseca da Silva, J. Dynamics of novel forests of Castilla elastica in Puerto Rico: From species to ecosystems. Ecol. Evol. 2015, 5, 3299-3311. [CrossRef] [PubMed]

21. Wright, I.J.; Reich, P.B.; Westoby, M.; Ackerly, D.D.; Baruch, Z.; Bongers, F.; Cavender-Bares, J.; Chapin, T.; Cornelissen, J.H.C.; Diemer, M.; et al. The worldwide leaf economics spectrum. Nature 2004, 428, 821-827. [CrossRef] [PubMed]

22. Vitousek, P.M. Biological invasions and ecosystem processes: Towards an integration of population biology and ecosystem studies. Oikos 1990, 57, 7-13. [CrossRef]

23. Funk, J.L.; Vitousek, P.M. Resource-use efficiency and plant invasion in low-resource systems. Nature 2007, 446, 1079-1081. [CrossRef] [PubMed]

24. Heard, M.J.; Sax, D.F. Coexistence between native and exotic species is facilitated by asymmetries in competitive ability and susceptibility to herbivores. Ecol. Lett. 2013, 16, 206-213. [CrossRef] [PubMed]

25. Fonseca da Silva, J. Species Composition, Diversity and Structure of Novel Forests of Castilla elastica in Puerto Rico. Trop. Ecol. 2014, 55, 231-244.

26. Francis, J.K.; Liogier, H.A. Naturalized Exotic Tree Species in Puerto Rico; General Technical Report SO-82; USDA Forest Service: New Orleans, LA, USA, 1991.

27. Sautu, A.; Baskin, J.M.; Baskin, C.C.; Condit, R. Studies on the seed biology of 100 native species of trees in a seasonal moist tropical forest, Panama, Central America. For. Ecol. Manag. 2006, 234, 245-263. [CrossRef] 
28. Ewel, J.; Whitmore, J.L. The Ecological life Zones of Puerto Rico and the U.S. Virgin Islands; Forest Service Research Paper ITF-18; USDA Forest Service, International Institute of Tropical Forestry: Río Piedras, Puerto Rico, 1973.

29. Viera-Martínez, C.A.; Abelleira Martínez, O.J.M.; Lugo, A.E. Estructura y química del suelo en un bosque de Castilla elastica en el Carso del norte de Puerto Rico: Resultados de una calicata. Acta Cient. 2008, 22, $29-35$.

30. Axelrod, F.S. A Systematic Vademecum to the Vascular Plants of Puerto Rico; Botanical Research Institute of Texas: Fort Worth, TX, USA, 2011.

31. Peek, M.S.; Russek-Cohen, E.; Wait, D.A.; Forseth, I.N. Physiological response curve analysis using nonlinear mixed models. Oecologia 2002, 132, 175-180. [CrossRef] [PubMed]

32. Evans, G.C.; Hughes, A.P. Plant growth and the aerial environment. I. Effect of artificial shading on Impatiens parviflora. New Phytol. 1961, 60, 150-180. [CrossRef]

33. Clark, D.B.; Clark, D.A.; Rich, P.M.; Weiss, S.; Oberbauer, S.F. Landscape-scale evaluation of understory light and canopy structures: Methods and application in a Neotropical lowland rain forest. Can. J. For. Res. 1996, 26, 747-757. [CrossRef]

34. Sakai, S. Thrips pollination of androdioecious Castilla elastica (Moraceae) in a seasonal tropical forest. Am. J. Bot. 2001, 88, 1527-1534. [CrossRef] [PubMed]

35. Mozdzer, T.J.; Zieman, J.C. Ecophysiological differences between genetic lineages facilitate the invasion of non-native Phragmites australis in North American Atlantic coast wetlands. J. Ecol. 2010, 98, 451-458. [CrossRef]

36. Kitajima, K.; Mulkey, S.S.; Wright, S.J. Seasonal leaf phenotypes in the canopy of a tropical dry forest: Photosynthetic characteristics and associated traits. Oecologia 1997, 109, 490-498. [CrossRef] [PubMed]

37. Reich, P.B.; Walters, M.B.; Ellsworth, D.S.; Uhl, C. Photosynthesis-nitrogen relations in Amazonian tree species. Oecologia 1994, 97, 62-72. [CrossRef] [PubMed]

38. Davidson, A.M.; Jennions, M.; Nicotra, A.B. Do invasive species show higher phenotypic plasticity than native species and, if so, is it adaptive? A meta-analysis. Ecol. Lett. 2011, 14, 419-431. [CrossRef] [PubMed]

39. Palacio López, K.; Gianoli, E. Invasive plants do not display greater phenotypic plasticity than their native or non-invasive counterparts: A meta-analysis. Oikos 2011, 120, 1393-1401. [CrossRef]

40. Reich, P.B.; Walters, M.B.; Ellsworth, D.S. From tropics to tundra: Global convergence in plant functioning. Proc. Natl. Acad. Sci. USA 1997, 94, 13730-13734. [CrossRef] [PubMed]

41. Davis, M.A.; Grime, J.P.; Thompson, K. Fluctuating resources in plant communities: A general theory of invasibility. J. Ecol. 2000, 88, 528-534. [CrossRef]

42. Grotkopp, E.; Rejmánek, M.; Rost, T.L. Toward a causal explanation of plant invasiveness: Seedling growth and life-history strategies of 29 pine (Pinus) species. Am. Nat. 2002, 159, 396-419. [CrossRef] [PubMed]

43. Shea, K.; Chesson, P. Community ecology theory as a framework for biological invasions. Trends Ecol. Evol. 2002, 17, 170-176. [CrossRef]

44. Lake, J.C.; Leishman, M.R. Invasion success of exotic plants in natural ecosystems: The role of disturbance, plant attributes and freedom from herbivores. Biol. Conserv. 2004, 117, 215-226. [CrossRef]

45. Hamilton, M.A.; Murray, B.R.; Cadotte, M.W.; Hose, G.C.; Baker, A.C.; Harris, C.J.; Licari, D. Life-history correlates of plant invasiveness at regional and continental scales. Ecol. Lett. 2005, 8, 1066-1074. [CrossRef]

46. Leishman, M.R.; Thomson, V.P. Experimental evidence for the effects of additional water, nutrients and physical disturbance on invasive plants in low fertility Hawkesbury Sandstone soils, Sydney, Australia. J. Ecol. 2005, 93, 38-49. [CrossRef]

47. Grotkopp, E.; Rejmánek, M. High seedling relative growth rate and specific leaf area are traits of invasive species: Phylogenetically independent contrasts of woody angiosperms. Ecology 2007, 94, 526-532. [CrossRef] [PubMed]

(C) 2017 by the authors. Licensee MDPI, Basel, Switzerland. This article is an open access article distributed under the terms and conditions of the Creative Commons Attribution (CC BY) license (http:/ / creativecommons.org/licenses/by/4.0/). 